Acta Theriologica 38 (3): 273 - 290, 1993.

PL ISSN $0001-7051$

\title{
Genetic variation in a fluctuating population of the yellow-necked mouse Apodemus flavicollis
}

\author{
Anna M. WÓJCIK
}

\begin{abstract}
Wójcik A. M. 1993. Genetic variation in a fluctuating population of the yellow-necked mouse Apodemus flavicollis. Acta theriol. 38: 273 - 290.

Protein polymorphism in 767 yellow-necked mice Apodemus flavicollis (Melchior, 1834), was studied in spring and autumn during five years in the Białowieża National Park, Eastern Poland. Two peaks and two declines of population number were observed, and population density varied from 3 to 63 inds/ha. Twenty three loci of proteins were studied, 4 of them were polymorphic; and mean heterozygosity of the studied population was $H=0.057$. The greatest variability was observed in the transferrin locus and 4 alleles $\left(T r f^{a}, T r f^{b}, T r f^{c}\right.$, and $\left.T r f^{d}\right)$ were described. The frequency of the $\operatorname{Tr} f^{a}$ allele and $\operatorname{Tr} f^{a} / T r f^{a}$ homozygotes was negatively correlated with population density in autumn, whereas the frequency of the $T r f^{c}$ allele and $T r f^{a} / T r f^{c}$ heterozygotes was positively correlated with population density in autumn. The frequency of heterozygotes was higher than the frequency of homozygotes during each spring. Significant excess of $\operatorname{Tr} f^{a} / T r f^{c}$ heterozygotes, compared to the values expected from the Hardy-Weinberg ratio, was observed in autumn 1983 and spring 1984, 1986, and 1987. Natural selection may be an important force in maintenance of the transferrin polymorphism in A. flavicollis. It is suggested that heterozygotes survive better than homozygotes during winter and at high population densities. It is also supposed that non-selective forces influence on the $\operatorname{Trf}$ allele frequency changes in the studied population of $A$. flavicollis.

Mammal Research Institute, Polish Academy of Sciences, 17-230 Białowieża, Poland

Key words: Apodemus flavicollis, genetic variation, transferrin, natural selection, population density
\end{abstract}

\section{Introduction}

The use of electrophoresis to identify the allozymic variation showed that plant and animal populations are genetically highly variable (Frydenberg and Simonsen 1973 , Nevo 1978, 1983). Electrophoretically variable proteins were often used as markers in studies concerning the factors involved in maintenance of genetic variation in populations. Natural selection, genetic drift, mutations, and migrations may change a gene pool. Since they usually act simultaneously in different combinations and intensities, there are many difficulties in interpretation of genetic variation in population. Population number changes may also influence the genetic structure of population.

Periodic fluctuations in population density were commonly observed in rodents, especially voles Microtinae. Many hypotheses have been proposed to explain the 
causes of population cycles (see e.g. Taitt and Krebs 1985). Chitty $(1960,1967)$ suggested that demographic changes are maintained by natural selection acting on genetic structure of population. In many studies, the frequency of alleles and genotypes correlated with population density in various rodents: Microtus (Semeonoff and Robertson 1968, Tamarin and Krebs 1969, Gaines and Krebs 1971, LeDuc and Krebs 1975, Gaines et al. 1978, Kohn and Tamarin 1978, Dobrowolska 1983, Gulyaeva 1983), Clethrionomys (Fedyk and Gębczyński 1980, Mihok et al. 1983, Hall and Semeonoff 1985, Kuryshev and Chernyavsky 1988), and Apodemus (Leigh Brown 1977). In spite of the correlations between genetic changes and density it was very difficult to distinguish the cause and effect of this phenomenon. Most of these studies were carried out in permanently reproducing vole populations, therefore, the changes of allele frequency associated with season and age structure of population were perhaps mixed with allele changes correlated with population fluctuations.

The yellow-necked mouse Apodemus flavicollis (Melchior, 1834) is characterized by fluctuations of population density. In woodlands of Central Europe, this species shows population dynamics patterns characterized by predominant seasonal variations and irregular multiannual fluctuations in numbers (review in Flowerdew 1985). Seasonal and multiannual fluctuations in population number were described by various authors in A. flavicollis from the Białowieża National Park (Adamczewska 1961, Grodziński et al. 1966, Wójcik and Wołk 1985, Wołk and Kozłowski 1989). Pucek et al. (1993) found that the extraordinarily high population numbers (outbreaks) in A. flavicollis occurred in 1977, 1983 and 1990 - one year after the mast (synchronous seed crop of oak, hornbeam, and maple) and was followed by rapid decline of numbers (crashes). All other years were characterized by intermediate abundance of mice. The analysis of cyclicity indices for autumn abundances showed, that intermediate years were characterized by very low values, typical of stable populations and outbreak-crash years were characterized by high cyclicity indices, typical of cyclic populations.

In the present study I investigated whether there are any correlations between seasonal and multiannual fluctuations in numbers and the genetic structure of A. flavicollis population. Thus, the specific aims of the present study were as follows: (1) description of protein variation in A. flavicollis; (2) analysis of changes of allele and genotype frequency of transferrin in relation to different seasons, population density, age, and body mass of animals; (3) an attempt to explain the factors involved in maintenance of transferrin polymorphism in A. flavicollis population.

\section{Material and methods}

\section{Trapping of mice and age determination}

A total of 767 yellow-necked mice was collected from autumn 1983 to spring 1988 in the Białowieża National Park in the mature deciduous forest (Querco-Carpinetum) composed of oak Quercus robur, linden Tilia cordata, and hornbeam Carpinus betulus, with admixtures of spruce Picea abies 
and few other tree species. Two hundred and eighty-eight live traps were distributed at $20 \mathrm{~m}$ intervals in a $12 \times 12$ grid of 5.76 ha (in 144 double stations). Mice were collected during 5 days twice a year; in spring (May) and autumn (September-October). In spring (April) 1988 trapping was conducted according to a different scheme. During 4 weeks, the catch-mark-release method was applied, and a small sample of blood from a tail of each mouse was collected into heparinized capillary for electrophoresis. Each mouse was marked by toe clipping at the first capture. At the end of May, a total of 19 from 27 marked mice were captured and brought to the laboratory.

Population density index (see Table 1) was calculated in two ways: (1) according to Zippin's formula based on maximum likelihood method (Southwood 1966), and (2) a total number of captured mice in following seasons divided by 5.76 ha of the trapping area. The index calculated by the second method was used to correlate population density and the frequency of transferrin alleles.

Captured mice were killed with chloroform in the laboratory. Body weight, sex, and reproductive condition were recorded. Skulls were removed for age determination.

Some pregnant females captured during spring seasons were housed singly in breeding cages till parturition. The females and their laboratory-born offspring were killed after parturition, and tissues were collected for electrophoresis. Blood samples only were collected from new-born mice.

Age of mice was determined on the basis of teeth growth and wear (Adamczewska-Andrzejewska 1967). Two age groups were distinguished: young ( $<3$ months) and adults ( $\geq 3$ months).

\section{Electrophoresis}

Blood, liver and kidney were used for screening all proteins. Blood was collected from heart and prepared for electrophoresis according to the method described by Selander et al. (1971). Tissues were frozen at $-20^{\circ} \mathrm{C}$ until use. Horizontal electrophoresis was performed with gels composed of $13 \%$ starch hydrolyzed in the laboratory. The following proteins systems were screened (abbreviation, E.C. number and tissue used are given in parentheses: H-hemolysate, K-kidney, L-liver, P-plasma): albumin (ALB, P), alcohol dehydrogenase (ADH, E.C. 1.1.1.1, L), esterases (ES, E.C. 3.1.1.1, H, P), glucose-6-phosphate dehydrogenase (G6PD, E.C. 1.1.1.49, L), glucose-phosphate isomerase (GPI, E.C. $5.3 .1 .9, \mathrm{~K}$ ), glutamate-oxaloacetate transaminase (GOT, E.C. 2.6.1.1, L), $\alpha$-glycerophosphate dehydrogenase (GPD, E.C. 1.1.1.8, K), hemoglobin (HB, H), indophenol oxidase (IPO, E.C. 1.15.1.1, K), lactate dehydrogenase (LDH, E.C. 1.1.1.27, K), leucine aminopeptidase (LAP, P), malate dehydrogenase (MDH, E.C. 1.1.1.37, K), malic enzyme (ME, E.C. 1.1.1.40, K), mannose phosphate isomerase (MPI, E.C. 5.3.1.8, K), phosphoglucomutase (PGM, E.C. 2.7.5.1, K), phosphogluconate dehydrogenase (PGD, E.C. 1.1.1.44, K), sorbitol dehydrogenase (SDH, E.C. 1.1.1.14, L) transferrin (TRF, P).

Buffers and staining procedures were used according to Selander et al. (1971), Harris and Hopkinson (1976) - MPI, and Tomaszewska-Guszkiewicz et al. (1971) - TRF.

Transferrin was stained in two ways: (1) gels were placed in $2 \%$ amido black $10 \mathrm{~B}$ solution and washed with ethanol : water : acetic acid $(5: 5: 1)$; (2) gels were placed in Nitroso R salt solution (Mueller et al. 1962) and washed with ethanol : water : acetic acid (5:5:1).

The genetic interpretation of electrophoretic patterns was based on analysis of bands on gels representative of homozygotes and heterozygotes. The information given by Harris and Hopkinson (1976) was also used for analysis of the structure of studied proteins. Presumptive alleles were designated alphabetically by their relative mobility, the allele variant migrating further anodically denoted as $A$.

Heterozygosity $(H)$ was estimated from electromorphic genotypes according to the method given by Nei (1978), and averaged across loci to estimate the percentage of loci heterozygous per individual per population.

\section{Statistical analysis}

Genetic differentiation between samples and deviations of $\operatorname{Trf}$ genotype frequencies from Hardy-Weinberg proportions in samples from following years were tested using Wright's (1965) 
$F$-statistics modified by Nei (1977). Significance of genotype excess and deficiency was tested using $\chi^{2}$-test:

$$
\chi^{2}=N F^{2}{ }_{I S}
$$

where $N$ is the total sample size ( $\mathrm{Li} 1955)$. Significance of allele frequency differences between populations was tested for each locus by the $\chi^{2}$-test:

$$
\chi^{2}=2 N F_{S T}(k-1)
$$

with $(k-1)(s-1)$ degrees of freedom, where $N$ is the total sample size, $k$ is the number of alleles for the locus, and $s$ is the number of populations (Workman and Niswander 1970).

Deviations from sex ratio 1:1, were tested by $G$-test for goodness of fit (Sokal and Rohlf 1981). Significance of allele and genotype frequency differences between samples collected in following years and seasons, and between samples of different age classes was tested using $G$-test of independence (Sokal and Rohlf 1981).

Relationships between body weight and genotype of transferrin among samples with two, one, and without the most common allele $\left(T r f^{a}\right)$ were tested by analysis of variance ANOVA using Statistical Graphics System STATGRAPHICS (version 5, 1991). Significance of differences in body weight between males and females, and between different age groups in successive seasons was tested using Student $t$-test.

The transformation arcsinp, where $p$ is the frequency of alleles or genotypes, was used for testing correlation between population density and allele and genotype frequencies.

\section{Results}

\section{Population density vs sex and age structure}

The number of captured mice varied in various seasons from 15 individuals in spring 1985 to 304 individuals in autumn 1983, and population density from 2.9 inds/ha to $62.8 \mathrm{inds} / \mathrm{ha}$, respectively (Table 1 ). Population density was rather stable during spring seasons (about 3-5 inds/ha) except the one in spring 1986 (13

Table 1. Number of trapped A. flavicollis, estimated population density and number of mice used for electrophoretical study. A - autumn, S - spring. n.e. - not estimated, *-calculated from total number of mice removed from the study plot during 5 days of trapping, ** - density index estimated only for four days trapping, due to trap damages caused by wild boars, *** -8 blood samples were collected from living animals in the field.

\begin{tabular}{lccccccccccc}
\hline $\begin{array}{l}\text { Year } \\
\text { Season }\end{array}$ & 1983 & \multicolumn{2}{c}{1984} & \multicolumn{2}{c}{1985} & \multicolumn{2}{c}{1986} & \multicolumn{2}{c}{1987} & \multicolumn{1}{c}{1988} \\
\hline$n$ trapped mice & 304 & 25 & 42 & 15 & 214 & 65 & 60 & 19 & 110 & 47 \\
$\begin{array}{l}\text { Zippin's density } \\
\text { index, } n \text { /ha }\end{array}$ & 62.8 & 4.7 & 7.3 & 2.9 & n.e. & 13.0 & 11.8 & 4.0 & $22.5^{* *}$ & 9.6 \\
$\begin{array}{l}\text { Density index*, } \\
n / \text { ha }\end{array}$ & 52.8 & 4.3 & 7.5 & 2.6 & 37.1 & 11.3 & 10.4 & 3.3 & 19.1 & 8.2 \\
$\begin{array}{l}\text { Samples used for } \\
\text { electrophoresis }\end{array}$ & 184 & 25 & 38 & 15 & 201 & 65 & 57 & $27^{* * *}$ & 109 & 46 \\
\hline
\end{tabular}




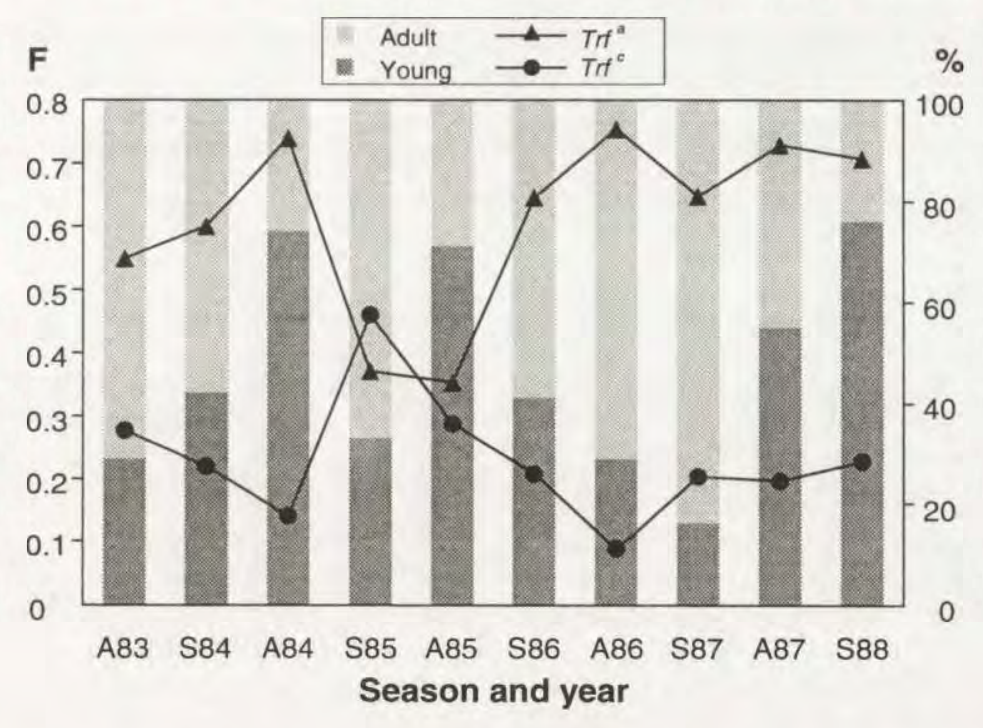

Fig. 1. Changes in frequency of $T r f^{a}$ (triangles) and $T r f^{c}$ (dots) alleles and percentage of adult and young individuals in the population of yellow-necked mouse (shaded bars). A - autumn, S - spring.

inds/ha). High fluctuations were observed during autumn seasons, with low density in 1984 and 1986, medium in 1987, and high in 1983 and 1985 (Table 1).

Sex ratio was closed to 1:1 in all study series, except the one from spring 1986, when significant excess of males was observed $(G=4.5, p<0.05)$. Age structure of studied population varied in seasons and years (Fig. 1), and depended on the beginning and duration of the breeding period.

\section{Genetic variation and heterozygosity}

Among 23 loci studied 19 were monomorphic (Alb, Adh, G6pd, Gpi, Got1, Got2, Gpd, Ipo, Ldh1, Ldh2, Lap, Mdh1, Mdh2, Me1, Me2, Mpi, Pgm1, Pgm3, Sdh) and 4 polymorphic ones (Pgd, Pgm2, Es 1, Trf ). The frequency of polymorphic loci was $P=0.17$. The mean heterozygosity calculated for 23 loci in a sample of 42 individuals from spring 1988 was $H=0.057$. In the case of three variable systems observed on gels (HB and two ES systems), it was not possible to determine the genetic mechanism of inheritance (Table 2).

\section{Polymorphic loci}

Phosphogluconate dehydrogenase was coded by one locus (Pgd). Three bands were observed, and the commonest one showed intermediate mobility towards the anode. Fast migrating and slow migrating bands occurred mainly in heterozygous state. 
Table 2. The allele frequencies and heterozygosites $(H)$ for each locus of studied proteins. ? - unscorable.

\begin{tabular}{|c|c|c|c|c|c|}
\hline Protein & Locus & Allele & $\begin{array}{c}n \\
\text { inds }\end{array}$ & $\begin{array}{c}\text { Allele } \\
\text { frequencies }\end{array}$ & $\begin{array}{l}\text { Heterozygosity } \\
(H)\end{array}$ \\
\hline ALB & $A l b$ & $a$ & 767 & 1 & 0 \\
\hline $\mathrm{ADH}$ & Adh & $a$ & 42 & 1 & 0 \\
\hline ES & $\begin{array}{l}\text { EsH } \\
\text { Es0 } \\
\text { Es1 }\end{array}$ & $\begin{array}{l}? \\
? \\
a \\
b\end{array}$ & $\begin{array}{l}245 \\
723 \\
723\end{array}$ & $\begin{array}{l}\overline{-} \\
\overline{0} \\
0.95 \\
0.05\end{array}$ & $\begin{array}{l}- \\
- \\
0.086\end{array}$ \\
\hline G6PD & G6pd & $a$ & 42 & 1 & 0 \\
\hline GPI & $G p i$ & $a$ & 42 & 1 & 0 \\
\hline GOT & Got1 & $a$ & 42 & 1 & 0 \\
\hline & Got2 & $a$ & 42 & 1 & 0 \\
\hline GPD & Gpd & $a$ & 42 & 1 & 0 \\
\hline HB & $H b$ & $?$ & 187 & - & - \\
\hline IPO & Ipo & $a$ & 42 & 1 & 0 \\
\hline LDH & $\begin{array}{l}L d h 1 \\
L d h 2\end{array}$ & $\begin{array}{l}a \\
a\end{array}$ & $\begin{array}{l}99 \\
99\end{array}$ & $\begin{array}{l}1 \\
1\end{array}$ & $\begin{array}{l}0 \\
0\end{array}$ \\
\hline LAP & Lap & $a$ & 42 & 1 & 0 \\
\hline $\mathrm{MDH}$ & $\begin{array}{l}\text { Mdh1 } \\
M d h 2\end{array}$ & $\begin{array}{l}a \\
a\end{array}$ & $\begin{array}{l}85 \\
85\end{array}$ & $\begin{array}{l}1 \\
1\end{array}$ & $\begin{array}{l}0 \\
0\end{array}$ \\
\hline ME & $\begin{array}{l}\mathrm{Me1} \\
\mathrm{Me2}\end{array}$ & $\begin{array}{l}a \\
a\end{array}$ & $\begin{array}{l}99 \\
99\end{array}$ & $\begin{array}{l}1 \\
1\end{array}$ & $\begin{array}{l}0 \\
0\end{array}$ \\
\hline MPI & $M p i$ & $a$ & 42 & 1 & 0 \\
\hline PGM & $\begin{array}{l}\text { Pgm1 } \\
\text { Pgm2 } \\
\text { Pgm3 }\end{array}$ & $\begin{array}{l}a \\
a \\
b \\
a\end{array}$ & $\begin{array}{l}42 \\
42 \\
\\
42\end{array}$ & $\begin{array}{l}1 \\
0.31 \\
0.69 \\
1\end{array}$ & $\begin{array}{l}0 \\
0.381 \\
0\end{array}$ \\
\hline PGD & Pgd & $\begin{array}{l}a \\
b \\
c\end{array}$ & 42 & $\begin{array}{l}0.07 \\
0.85 \\
0.08\end{array}$ & 0.262 \\
\hline $\mathrm{SDH}$ & $S d h$ & $a$ & 42 & 1 & 0 \\
\hline TRF & $T r f$ & $\begin{array}{l}a \\
b \\
c \\
d\end{array}$ & 767 & $\begin{array}{l}0.61 \\
0.14 \\
0.24 \\
0.01\end{array}$ & 0.515 \\
\hline
\end{tabular}

Phosphoglucomutase was polymorphic and three phenotypes were observed in Pgm2 locus: a fast migrating anodal band, a slow migrating band, and a twobanded phenotype. These phenotypes suggest that the isoenzyme is a monomer. 
Hemoglobin $(\mathrm{Hb})$ migrated towards the anode. A wide band was observed in all studied mice and a narrow additional faster migrating band was found in some individuals. It was not possible to decide whether this variation had a genetic base, and the enzyme was not included in the calculation of population heterozygosity.

A large number of esterase isoenzymes were found in erythrocytes and plasma of $A$. flavicollis those made visible by three stains, based on the substrates $\alpha$-naphtyl acetate, $\alpha$-naphtyl butyrate, and $\alpha$-naphtyl propionate. Only three esterases migrating anodally were scored: the one in erythrocytes migrating faster than hemoglobin and two ones, migrating fast, in plasma. The locus Es1 migrating fast in plasma (stained using $\alpha$-naphtyl acetate) showed clear variation. Three phenotypes were found in this locus and the enzyme was believed to be a monomer. Homozygotes were represented by a one-banded phenotype and heterozygotes by a two-banded phenotype. In the case of two other polymorphic loci, $E s H$ and $E s O$, it was not possible to determine the genetic base of this variation.

Transferrin $(T r f)$ was a monomer, which migrated towards the anode. The analysis of transferrin phenotypes of 7 females and their 34 offsprings showed that young had at least one allele common with their mother. It was found that the transferrin patterns in A. flavicollis were controlled by four alleles at an autosomal locus: $\operatorname{Tr} f^{a}, \operatorname{Tr} f^{b}, \operatorname{Tr} f^{c}$, and $\operatorname{Tr} f^{d}$. A one-banded phenotype in homozygotes and a two-banded phenotype in heterozygotes were observed.

No differences were found in the transferrin patterns and genotype frequency in 24 pregnant females and other studied females captured in spring seasons $(G=6.19, \mathrm{df}=7, p>0.3)$. Also, no differences were found in transferrin phenotypes of mice whose blood was sampled two times during 4 weeks in spring 1987 . These results suggest that physiological conditions of animals did not influence the transferrin variation in A. flavicollis.

\section{Transferrin polymorphism}

The frequency of transferrin alleles in the whole sample of mice was estimated: $\operatorname{Tr} f^{a}=0.61, \operatorname{Tr} f^{b}=0.14, \operatorname{Tr} f^{c}=0.24$, and $\operatorname{Tr} f^{d}=0.01$. Significant differences of $T r f$ allele frequency between samples from all seasons were found $\left(F_{S T}=0.0445\right.$, $\chi^{2}=204.97, \mathrm{df}=27, p<0.001$ ). No differences were found in $\operatorname{Trf}$ genotype and allele frequencies between sexes, and between young and adult mice in the whole material and in samples from consecutive seasons.

The frequency of transferrin alleles varied in samples from different seasons (Table 3). $\operatorname{Trf}^{a}$ was the most common allele, except spring 1985, when the frequency of $T r f^{c}$ allele was higher than the frequency of $T r f^{a}$. The frequency of $T r f^{d}$ was very low and this allele was only found in heterozygous state. The frequency of $\operatorname{Tr} f^{a}$ and $\operatorname{Tr} f^{c}$ alleles was not significantly correlated with the frequency of young and adult mice (Fig. 1).

Significant differences in the frequency of $\operatorname{Tr} f^{a} / \operatorname{Tr} f^{a}$ homozygotes and $\operatorname{Tr} f^{a} / \operatorname{Tr} f^{c}$ heterozygotes in various samples were found $(G=27.5, \mathrm{df}=9, p<0.01)$. The 


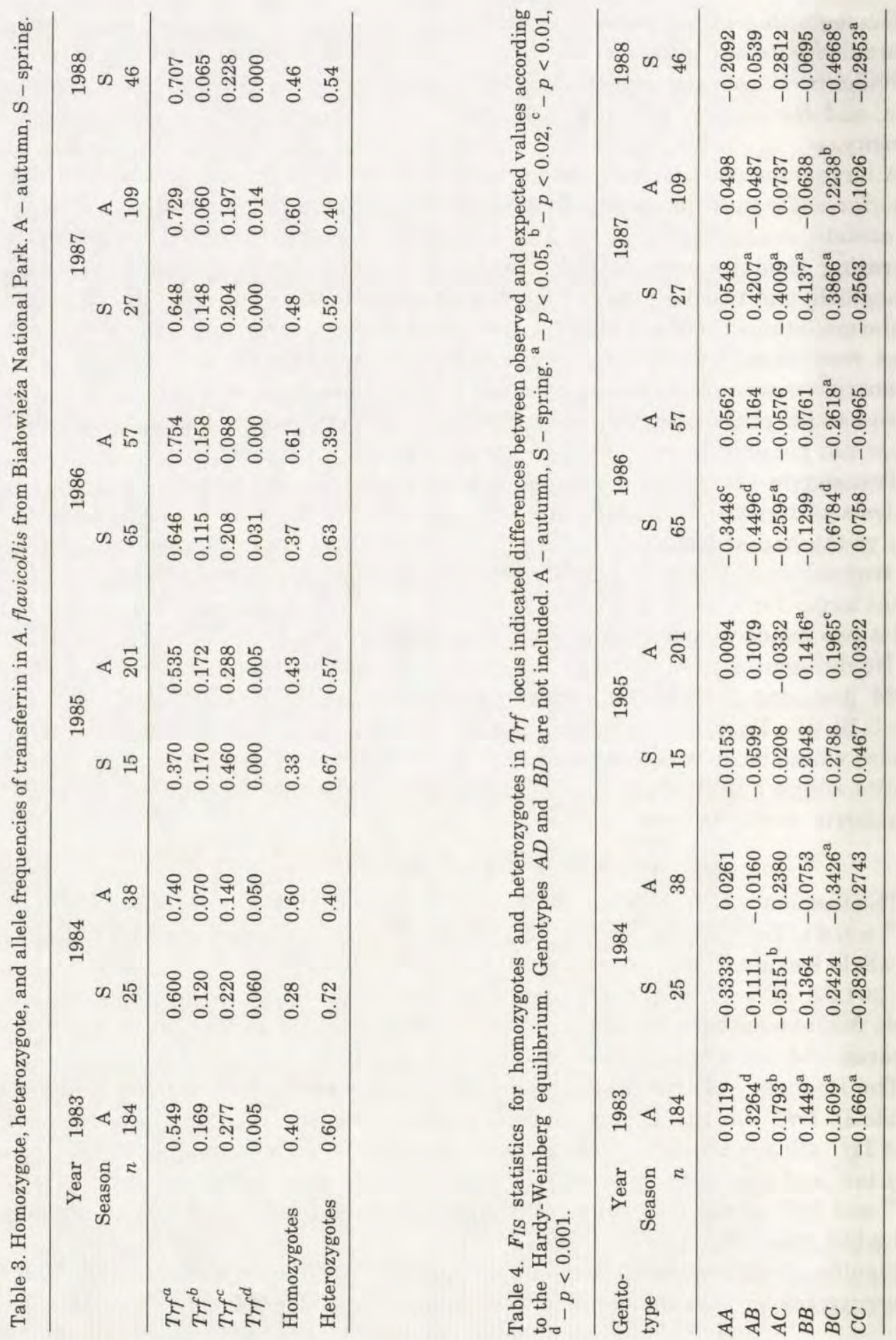




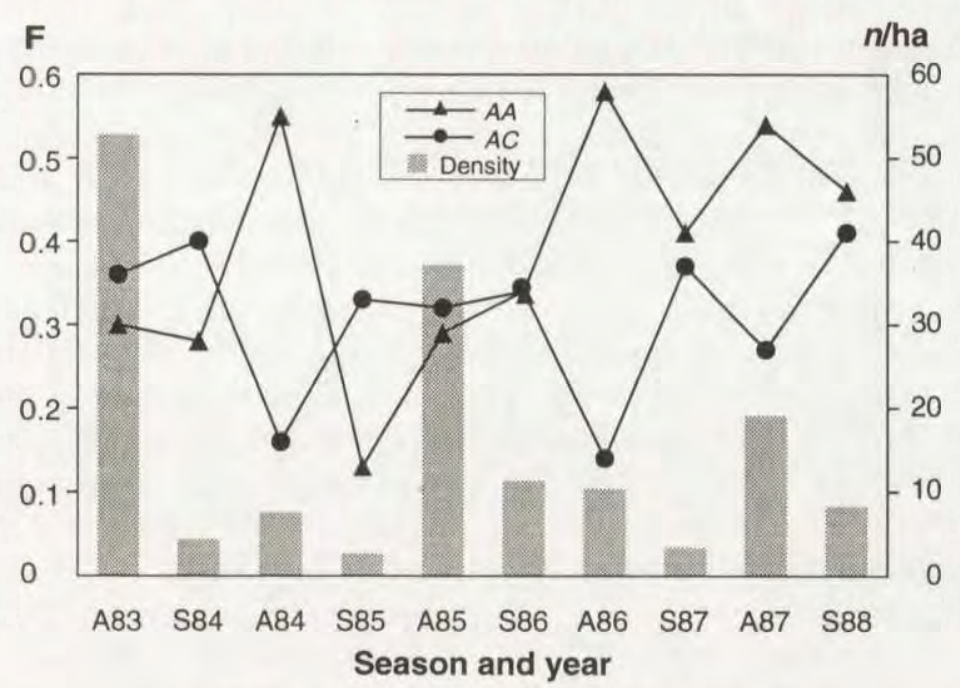

Fig. 2. Changes in frequency of $\operatorname{Tr} f^{a} / \operatorname{Tr} f^{a}$ (triangles) and $\operatorname{Tr} f^{a} / \operatorname{Tr} f^{c}$ (dots) genotypes and numbers of yellow-necked mouse (shaded bars). A - autumn, S - spring.

frequency of heterozygotes was higher than the frequency of homozygotes during spring of each year and in autumn 1983 and 1985, whereas a reverse proportion was observed during autumn 1984, 1986, and 1987 (Table 3).

The $F_{I S}$-statistics (a measure of deviations of genotype frequencies from Hardy-Weinberg proportions) varied in various samples (Table 4). Significant excess of $\operatorname{Tr} f^{a} / T r f^{c}$ heterozygotes was observed in autumn 1983 and in spring 1984, 1986, and 1987. Deficiency of $\operatorname{Tr} f^{a} / T r f^{a}$ homozygotes was observed during each spring, but only the value from spring 1986 was statistically significant. In the cases of other transferrin genotypes, significant deviations from Hardy-Weinberg proportions existed in some seasons but no clear directions of these differences were seen.

A clear frequency variation of the most common $\operatorname{Trf}$ genotypes was observed (Fig. 2). The frequency of $\operatorname{Tr} f^{a} / \operatorname{Tr} f^{a}$ homozygotes increased from spring to autumn,

Table 5. Correlation coefficients between $T r f$ allele frequency and population density, and between $\operatorname{Tr} f^{a} / T r f^{a}$ homozygote and $\operatorname{Tr} f^{a} / \operatorname{Tr} f^{c}$ heterozygote frequencies and population density of A. flavicollis. ${ }^{*}-p<0.05$, ** $-p=0.05$.

\begin{tabular}{|c|c|c|c|c|c|}
\hline Season & $n$ & $\operatorname{Tr} f^{a}$ & & $T r f^{b}$ & $\operatorname{Tr} f^{c}$ \\
\hline Spring & 5 & 0.585 & & -0.647 & -0.494 \\
\hline \multirow[t]{2}{*}{ Autumn } & 5 & $-0.927^{*}$ & & 0.606 & $0.874^{* *}$ \\
\hline & & & $\operatorname{Tr} f^{a} / T r f^{a}$ & \multicolumn{2}{|c|}{$\operatorname{Tr} f^{a} / \operatorname{Tr} f^{c}$} \\
\hline Autumn & 5 & & $-0.929^{*}$ & \multicolumn{2}{|c|}{$0.924^{*}$} \\
\hline
\end{tabular}


while the frequency of $\operatorname{Tr} f^{a} / T r f^{c}$ heterozygotes declined. Significant differences between frequencies of these genotypes were found in $1984(G=6.04, \mathrm{df}=1, p<$ $0.02)$ and in $1986(G=8.9, \mathrm{df}=1, p<0.01)$. There were significant differences between frequencies of the $\operatorname{Tr} f^{a} / \operatorname{Tr} f^{a}$ and $\operatorname{Tr} f^{a} / \operatorname{Tr} f^{c}$ genotypes in autumn 1984, 1986, and $1987(G=29.43, \mathrm{df}=4, p<0.001)$. In these seasons, the frequency of $\operatorname{Tr} f^{a} / T r f^{a}$ was 2-3 times higher than the frequency of $\operatorname{Tr} f^{a} / T r f^{c}$.

A strong negative correlation between the frequency of $T r f^{a}$ allele, and a strong positive correlation between the frequency of $\operatorname{Trf}^{c}$ allele and population density were found in autumn. Also, there were significant correlations between the frequency of $\operatorname{Tr} f^{a} / T r f^{a}$ homozygotes and the population density in autumn as well as the frequency of $\operatorname{Tr} f^{a} / T r f^{c}$ heterozygotes and the autumn density of mice (Table 5). No significant correlation was found between the frequency of $\operatorname{Tr} f$ allele and genotypes and population density of A. flavicollis in spring.

No significant differences between body weight of homozygous $\left(\operatorname{Tr} f^{a} / \operatorname{Tr} f^{a}\right)$ and heterozygous individuals $\left(\operatorname{Tr} f^{a} / \operatorname{Tr} f^{b}, \operatorname{Tr} f^{a} / T r f^{c}\right)$ in age and sex groups from various seasons were found. Body weight was not associated with transferrin genotypes in age and sex groups of the whole sample. Body weight of the $\operatorname{Tr} f^{a} / \operatorname{Tr} f^{a}$ homozygotes, heterozygotes with the $\operatorname{Tr} f^{a}$ allele, and other $\operatorname{Tr} f$ genotypes without the $\operatorname{Tr} f^{a}$ allele did not differ statistically.

\section{Discussion}

The mean heterozygosity $(H=0.057)$ and the frequency of polymorphic loci $(P=0.17)$ in A. flavicollis population from Białowieża Forest was similar to those found in populations from different parts of the species range (Table 6).

Among various proteins, transferrin showed a clear variation in the studied population of A. flavicollis. Transferrin polymorphism was also described in various populations of this species (see Table 6), as well as, in different Apodemus species: A. agrarius (Dobrowolska and Chabros 1978), A. giliam (Moriwaki et al. 1971), A. sylvaticus (Gemmeke 1980), and A. penninsulae (Pavlenko et al. 1984).

Transferrin was studied in many other rodent species, e.g.: Microtus pennsylvanicus, M. ochrogaster, M. townsendii (Maurer 1967, Tamarin and Krebs 1969, Gaines and Krebs 1971, Gaines et al. 1971), Clethrionomys rutilus, C. gapperi (Canham and Cameron 1972), Peromyscus polionotus (Griswold and Dawson 1971) Peromyscus maniculatus (Dewsbury 1985), Mus musculus (Ashton and Dennis 1970). All these results suggest that transferrin variation is genetically controlled.

Nevertheless, some doubts have been raised about the reliability of transferrin electromorphs as genetic markers. Results of some studies suggested that the animal's physiological condition and environmental factors may influence transferrin variation. Gulyaeva and Olenev (1979) found that staining intensity of minor transferrin band changed during the reproductive cycle in Clethrionomys glareolus females and it was the strongest during pregnancy. They suggested that this 


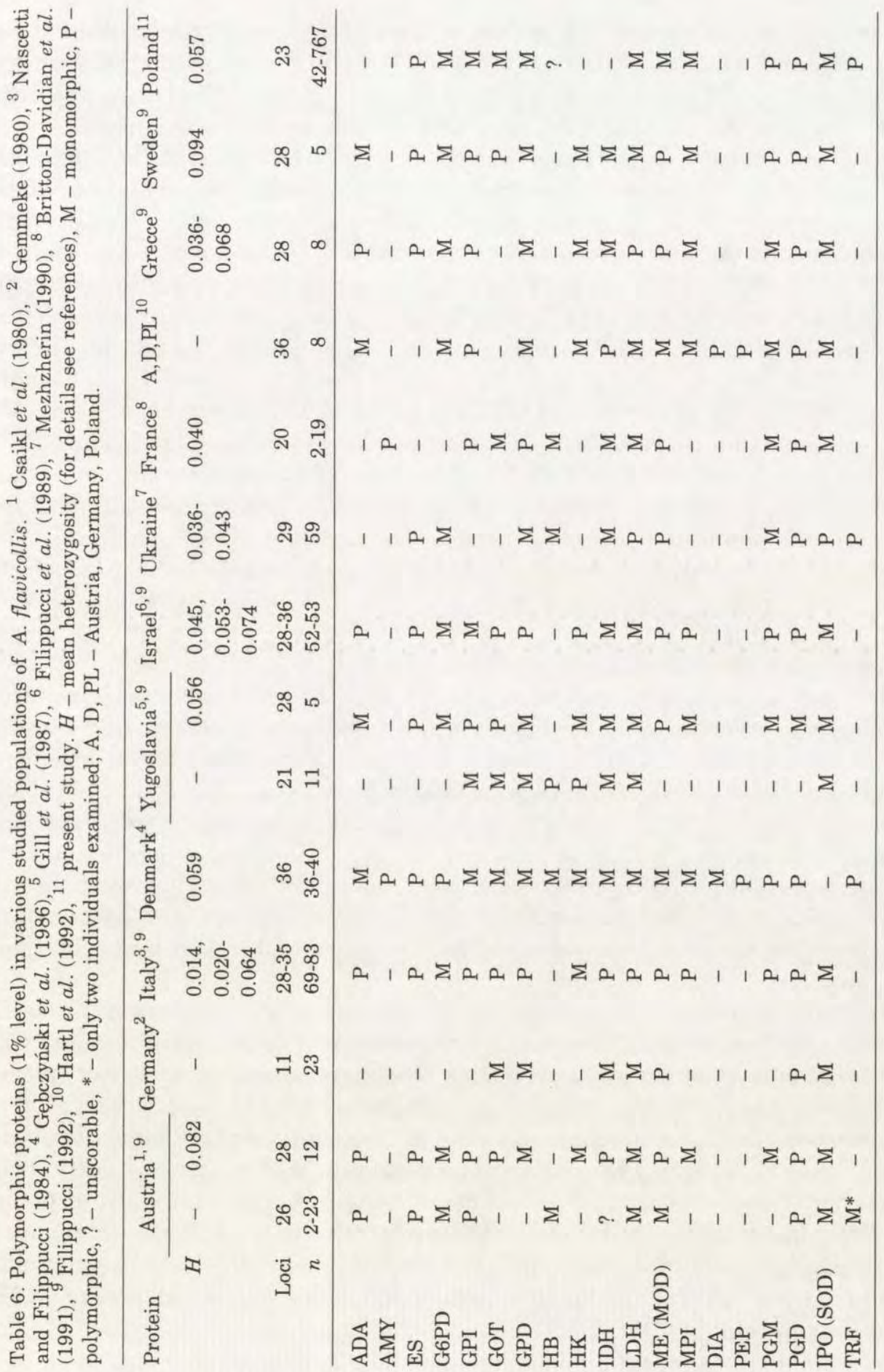


phenomenon was caused by higher iron saturation of transferrin in blood of pregnant females. However, Mihok et al. (1983) did not support the relative iron saturation of transferrin in various individuals of C. gapperi. McGovern and Tracy (1981) observed the changes in the mobility of transferrin electromorphs in field caught $M$. ochrogaster exposed to different temperature regimes in the laboratory. They questioned the suitability of transferrin as a marker in population studies of microtine rodents. In contrary, Mihok and Ewing (1983) studied transferrin in the same individuals in different period of their lives, and found the complete reliability of transferrin electromorphs in $M$. pennsylvanicus. It is also noteworthy that Gulyaeva and Olenev's (1979) and McGovern and Tracy's (1981) results are not consistent with extensive mating data on the transferrin system in Clethrionomys, Microtus, Peromyscus and Mus species (see e.g. Maurer 1967, Tamarin and Krebs 1969, Gaines and Krebs 1971, Gaines et al. 1971, Canham and Cameron 1972, Griswold and Dawson 1971, Dewsbury 1985, and Ashton and Dennis 1971).

In my study, no differences were found in transferrin electromorphs of A. flavicollis females in different phases of the reproductive period, and all genotypes found in this population occurred both in females and males. The analysis of transferrin electromorphs in females and their offspring suggested that transferrin variation is genetically controlled. Thus, I believe that an individual physiological condition does not affect transferrin electromorphs, and this protein can be used as genetic marker in population study.

Transferrin is capable of inhibiting or arresting the growth of a variety of iron-dependent microorganisms, many of which are pathogens (Schade and Caroline 1944, Kochan et al. 1969, cited after Allendorf and Leary 1986). It was also found that heterozygous transferrin of pigeons Columba livia and ring-necked pheasants Phasianus colchicus had a greater inhibitory effect on the growth of iron-dependent microorganisms than either of the homozygous transferrins (Frelinger 1972, Lucotte and Kaminski 1976, cited after Ferguson 1980). It is suggested that the greater ability of heterozygous eggs to resist microbial infection is at least partially responsible for the maintenance of transferrin polymorphism in birds (Frelinger 1972, cited after Ferguson 1980).

It seems, therefore, that also the $\operatorname{Tr} f$ heterozygous individuals of A. flavicollis have greater ability than the homozygous ones to inhibit the growth of iron-dependent microorganisms. Possibly, this ability is responsible for better survival of heterozygotes in winter and in high population density. Excess of $\operatorname{Tr} f^{a} / \operatorname{Tr} f^{c}$ heterozygotes in three spring samples of A. flavicollis and in high population number may be explained by a heterozygote advantage in winter and early spring and in high population density. The heterozygote advantage may also explain a high heterozygosity in $\operatorname{Tr} f$ locus during spring seasons and the maintenance of the transferrin polymorphism in A. flavicollis. Similar results have been obtained by Mihok et al. (1983) in Clethrionomys gapperi and by Pemberton et al. (1988) in red deer Cervus elaphus. 
The direction and intensity of natural selection on proteins of different species have been studied. Tamarin and Krebs (1969) found that usually the $\operatorname{Tr} f^{E} / \operatorname{Trf}^{E}$ homozygotes in $M$. ochrogaster had a better survival than the other transferrin genotypes. Certain $\operatorname{Trf}$ and Lap genotypes were favored during the increase phase of a population cycle of $M$. ochrogaster, while others were favored in the decline phase (Gaines and Krebs 1971). Significant differences in breeding activity, growth rates, and mean body weights among different Trf and Lap genotypes were found (Gaines et al. 1978). Birdsall (1974) suggested that deviation of genotypic frequencies from Hardy-Weinberg ratio may be interpreted as evidence for natural selection acting on the $\operatorname{Tr} f$ and Lap loci in fluctuating populations of $M$. pennsylvanicus. Different patterns of deviations in the proportion of genotypes at the two loci during the density cycle were found. There was a significant excess of $\operatorname{Trf}$ heterozygous males in the decline phase, whereas a significant excess of Lap heterozygous males was recorded in the increase phase (Birdsall 1974).

Although natural selection may play an important role in maintaining polymorphism, non-selective forces (e.g. genetic drift and migration) may also influence the changes of allele frequency in populations. Gaines and Whittam (1980) found that the intensity of selection was not strong enough to counteract the effects of non-selective forces, such as genetic drift, in fluctuating $M$. ochrogaster population.

The studied A. flavicollis population from Białowieża was characterized by a high rate of winter mortality, and population density during spring was usually low. Therefore, a genetic drift may affect genotype frequency changes in the population (bottleneck). This probably occurred in spring 1985, when the frequency of $\operatorname{Tr} f^{c}$ allele increased significantly, whereas in other seasons, the $\operatorname{Tr} f^{a}$ allele was the most common one. Results obtained from epigenetic variation study showed that the sample from spring 1985 was significant different from the other samples in this A. flavicollis population (M. D. Sikorski and A. M. Wójcik, unpubl.).

The regularly observed bottlenecks in population density should result in a decline of allele number during periods of low densities. This was not observed in the studied A. flavicollis pepulation. Moreover, the Trf frequency changes from autumn to spring were not random, but a similar change pattern was found in consecutive years. Thus, it may be suggested that the genetic drift was not a main force causing the $\operatorname{Trf}$ frequency changes in A. flavicollis.

Mating system may also affect the changes in genetic structure of population. It is suggested that A. flavicollis is characterized by a typical polygamy (Gliwicz 1988). Mature males perhaps maintain individual territories that are actively defended against other males. Several females may live on a male territory, and non-territorial males have a little chance to mate with them. Thus, genotypes of territorial males may have an important effect on genetic structure of population. Considerabley high frequency of certain allele in breeding (territorial) males should affect an increase of homozygosity in the next generation. This might have occurred in the studied population of A. flavicollis from Białowieża Forest in the 
case of the $\operatorname{Tr} f^{a}$ allele; the increase of $\operatorname{Tr} f^{a} / \operatorname{Tr} f^{a}$ homozygote frequency from spring to autumn was observed in each year (Fig. 2).

Smith et al. $(1975,1978)$ and Garten (1976) found a positive correlation between mean heterozygosity, and population density in Peromyscus polionotus. Similar results have been obtained in populations of C. glareolus (Leitner and Hartl 1988) and P. maniculatus (Baccus and Wolff 1989). Smith et al. (1975) suggested that in low population densities inbreeding decreased heterozygosity, while in high densities, there was an increased dispersal and the population became relatively more outbred, leading to increased heterozygosity. A positive correlation between the heterozygote frequency in $\operatorname{Trf}$ locus and the population density in A. flavicollis was found in this study as predicted Smith et al. (1975).

Chitty (1967) proposed a genetic-behavioral hypothesis to explain multiannual density cycles in microtine rodents. The major principle of this hypothesis is that demographic changes are mediated by natural selection operating on the genetic structure of the population. According to Chitty's (1967) hypothesis allele frequency changes should be closely associated with density.

Several studies in different Microtus species confirmed that correlations between allele frequency changes in certain loci and density were consistent with Chitty's (1967) hypothesis, but it was difficult to distinguish cause and effect (Tamarin and Krebs 1969, Gaines and Krebs 1971, LeDuc and Krebs 1975, Gaines et al. 1978, Kohn and Tamarin 1978). Genetic changes may cause demographic changes or they may be an effect of density changes. Computer simulations carried out by Charlesworth and Giesel (1972) showed that a correlation between allele frequency and population density could be produced by a change in the rate of population growth. These results suggested that fluctuations in allele frequency could be a side effect of population cycles (see Charlesworth 1980, Gaines 1985). Gaines (1985) discussed evidences supporting Charlesworth and Giesel's (1972) contention that changes in allele frequency are effects of density changes. He summarized that, in spite of evidences from a number of studies confirming close correlations between allele frequency changes and density in Microtus populations, it is an error to interpret these association as support for Chitty's (1967) hypothesis. Strong correlations between the $\operatorname{Tr} f$ allele frequency changes and population density was also found in A. flavicollis in the present study, but this does not seem to support Chitty's (1967) hypothesis. Theoretical and field studies (mainly in Microtus species) suggest that allele frequency changes at a single locus were effects of demographic changes of population rather than vice versa (see also Gaines 1985).

In summary, there are strong evidences that $\operatorname{Trf}$ allele frequency changes are closely associated with population density changes in a number of species of the genus Microtus, Clethrionomys and Apodemus. Natural selection may be an important force in maintenance of the transferrin polymorphism in small rodents. The excess of $\operatorname{Trf}$ heterozygotes in spring samples of A. flavicollis, compared to the expected number based on Hardy-Weinberg equilibrium, suggested that a 
heterozygote advantage during winter and early-spring seasons is an important factor responsible for transferrin variation. Population density fluctuations, social structure, and mating system may also modify gene frequency changes. Future investigations concerning the physiological significance of transferrin and other protein polymorphisms will work towards our understanding of mechanisms responsible for the maintenance of genetic variation in natural populations. Finally, as Gaines (1985) proposed: "in the future, attempts to relate genetic structure to population regulation must focus on those traits deemed ecologically relevant".

Acknowledgements: I am grateful to Prof M. Gębczyński for encouragement and careful instruction during this study. I wish to thank Profs H. Krzanowska, Z. Pucek, and J. Kozłowski for useful criticisms and comments on earlier draft of this paper. I am grateful to my husband Dr J. M. Wójcik for his help in all stages of the work and translating the paper into English. I thank Dr B. Jędrzejewska for critical reading of the manuscript and checking the English and Dr E. Wołk for methodological advices. I also thank J. Lipińska, U. Niedzielska, and L. Szymura for their assistance in the field and with the electrophoretic analysis and S. Buszko, W. Szpakowicz, and J. Siemieniuk for their help in collecting material. The study was supported by the grant CPBP 04.03 .

\section{References}

Adamczewska K. A. 1961. Intensity of reproduction of the Apodemus flavicollis (Melchior 1834) during the period $1954-1959$. Acta theriol. $5 ; 1-21$.

Adamczewska-Andrzejewska K. 1967. Age reference model for Apodemus flavicollis (Melchior, 1834). Ekol. Pol. A. 15: 787 - 790 .

Allendorf F, W. and Leary R. F. 1986. Heterozygosity and fitness in natural population of animals. [In: Conservation Biology: The science of scarcity and diversity. M. E. Soule, ed]. Sinauer Associates, Sunderland, Massachusetts: $57-76$.

Ashton G. C, and Dennis M. N. 1971. Selection at the transferrin locus in mice. Genetics 67: 253-265.

Baccus R. and Wolff J. O. 1989. Genetic composition of fluctuating population of Peromyscus leucopus and Peromyscus maniculatus. J. Mammal, 70: 592 - 602.

Birdsall D. A. 1974. An analysis of selection at two loci in fluctuating population of Microtus. Can. J. Zool. 52: 1457 - 1462 .

Britton-Davidian J., Vahdati M., Benmehdi F., Gros P., Nance V., Croset H., Gerasimov S. and Triantaphyllidis C. 1991. Genetic differentiation in four species of Apodemus from Southern Europe: A. sylvaticus, A. flavicollis, A. agrarius and A. mystacinus (Muridae, Rodentia). Z. Säugetierk. 56: $25-33$.

Canham R. P. and Cameron D. G. 1972. Variation in the serum proteins of the red-backed mice Clethrionomys rutilus and C. gapperi and its taxonomic significance. Can. J. Zool. 50: 217 - 227

Charlesworth B. 1980. Evolution in age-structured populations. Cambridge Univ. Press, London: $1-300$.

Charlesworth B. and Giesel J. T. 1972. Selection in populations with over-lapping generations. II. Relations between gene frequency and demographic variables. Amer. Nat. 106: 388 - 401 .

Chitty D. 1960. Population processes in the vole and their relevance to general theory. Can. J. Zool. 38: $99-113$.

Chitty D. 1967. The natural selection of self-regulatory behaviour in animal populations. Proc. Ecol. Soc. Australia 2: $51-78$.

Csaikl F., Engel W. and Schmidtke J. 1980. On the biochemical systematics of three Apodemus species. Comp. Biochem. Physiol. 65B: $411-414$.

Dewsbury D. A. 1985. Studies of the effects of variation at the transferrin locus on reproductive processes in deer mice. Acta theriol. 30: $227-240$. 
Dobrowolska A. 1983. Variability in transferrins and gamma-globulin level of blood serum in the common vole. Acta theriol. 28: $209-224$.

Dobrowolska A. and Chabros E. 1978. Serum proteins of Apodemus agrarius (Pall. 1785) from different urban environments. Bull. Acad. pol. Sci. Cl. II, Ser. Sci. biol. 26: $337-342$.

Fedyk A. and Gębczyński M. 1980. Genetic changes in seasonal generations of the bank vole. Acta theriol, $25 ; 475-485$.

Ferguson A. 1980. Biochemical systematics and evolution. Blackie, Glasgow and London: $1-194$.

Filippucci M. G. 1992. Allozyme variation and divergence among European, Middle Eastern, and North African species of the genus Apodemus (Rodentia, Muridae). Isr. J. Zool. 38: 193-218.

Filippucci M. G., Simson S. and Nevo E. 1989. Evolutionary biology of the genus Apodemus Kaup, 1829 in Israel. Allozymic and biometric analyses with description of a new species: Apodemus hermonensis (Rodentia, Muridae). Boll. Zool. 56: $361-376$.

Flowerdew J. B. 1985. The population dynamics of wood mice and yellow-necked mice. [In: The ecology of woodland rodents bank voles and wood mice. J. R. Flowerdew, J. Gurnell and J. H. W. Gipps, eds]. Symp. zool. Soc. Lond. 55: $315-338$.

Frelinger J. A. 1972. The maintenance of transferrin polymorphism in pigeons. - Proc. Nat. Acad. Sci. USA, $69: 326-329$.

Frydenberg O, and Simonsen V. 1973. Genetics of Zoarces populations. V. Amount of protein polymorphism and degree of genic heterozygosity. Hereditas 75: $221-232$.

Gaines M. S. 1985. Genetics. [In: Biology of New World Microtus. R. H. Tamarin, ed]. Special Publ. Amer, Soc. Mammal. 8, Boston: $845-883$.

Gaines M. S. and Krebs C. J. 1971. Genetic changes in fluctuating vole populations. Evolution 25: 702 -723 .

Gaines M. S. and Whittam T. S. 1980. Genetic changes in fluctuating vole populations: selective vs nonselective forces. Genetics 96: $767-778$.

Gaines M. S., Myers J. H. and Krebs C. J. 1971. Experimental analysis of relative in transferrin genotypes of Microtus ochrogaster. Evolution 25: 443-450.

Gaines M. S., McClenaghan L. R. and Rose R. K. 1978. Temporal patterns of allozymic variation in fluctuating populations of Microtus ochrogaster. Evolution 32: 723 - 739 .

Garten C. T. 1976. Relationships between aggressive behavior and genetic heterozygosity in the old field mouse, Peromyscus polionotus. Evolution 30: 59-72.

Gemmeke H. 1980. Proteinvariation und Taxonomie in der Gattung Apodemus (Mammalia, Rodentia). Z. Säugetierk. $45: 348-366$.

Gębczyński M., Nielsen J. T. and Simonsen V. 1986. An electrophoretic comparison between three sympatric species of rodents from Jutland, Denmark. Hereditas 104: 55 - 59.

Gill A., Petrov B., Zivković S. and Rimsa D. 1987. Biochemical comparisons in Yugoslavian rodents of the families Arvicolidae and Muridae. Z. Säugetierk. 52: 247 - 256.

Gliwicz J. 1988. Życie intymne myszy. Wiad. Ekol. 34: 187 - 202. [In Polish with English summary]

Griswold K. E. and Dawson W. D. 1971. Transferrin and haptoglobin inheritance in Peromyscus. J. Heredity 62: $339-341$.

Grodziński W., Pucek Z. and Ryszkowski L. 1966. Estimation of rodent numbers by means of prebaiting and intensive removal. Acta theriol. 11: 297 - 314.

Gulyaeva I. P. 1983. Genetic changes in narrow-skulled population during different phases of fluctuation. Genetika 19: 75 - 81. [In Russian with English summary]

Gulyaeva I. P. and Olenev G. V. 1979. [Variations in the electrophoretic pattern of serum transferrins in the common red-backed vole as a function of the animal's physiologic state]. Ekologija 6: 47 - 52. [In Russian]

Hall S. J. G. and Semeonoff R. 1985. Plasma esterase polymorphism in the bank vole, Clethrionomys glareolus in Britain. J. Zool., Lond. (A) 207: 213 - 222.

Harris H. and Hopkinson D. A. 1976. Handbook of enzyme electrophoresis in human genetics. North Holland Publishing Company, Amsterdam and Oxford, Amsterdam and Oxford. 
Hartl G. B., Suchentrunk F., Willing R., Markowski J. and Ansorge H. 1992. Inconsistency of biochemical evolutionary rates affecting allozyme divergence within the genus Apodemus (Muridae: Mammalia). Biochem. Syst. Ecol, 20: 363 - 372.

Kochan I., Golden C. A. and Bukovic J. A. 1969. Mechanism of tuberculostasis in guinea pigs. J. Bacteriol. 100: $64-70$.

Kohn P. H. and Tamarin R. H. 1978. Selection of electrophoretic loci for reproductive parameters in island and mainland voles. Evolution 32: $15-28$.

Kuryshev S. V. and Chernyavsky F. B. 1988. Variability of genetic structure of fluctuating populations of red-backed voles (Clethrionomys, Rodentia, Cricetidae). Zool. そ̌. 67: $215-222$. [In Russian with English summary]

LeDuc J. and Krebs C. J. 1975. Demographic consequences of artificial selection at the LAP locus in voles (Microtus townsendii). Can. J. Zool. 53: 1825-1840.

Leigh Brown A. J. 1977. Genetic changes in a population of field mice (Apodemus sylvaticus) during winter. J. Zool., Lond. 182: $281-289$.

Leitner M. and Hartl G. B. 1988. Genetic variation in the bank vole Clethrionomys glareolus: Biochemical differentiation among populations over short geographic distances. Acta theriol. 33: $231-245$

Li C. C. 1955. Population genetics. University of Chicago Press, Chicago: $1-366$.

Lucotte G. and Kaminski M. 1976. Molecular heterosis at the conalbumin locus in the ring-necked pheasant (Phasianus colchicus). Theor. appl. Genet. 48: $251-253$.

Maurer F. W. 1967. Heritability of transferrin protein in three species of Microtus. Nature 215: 95 - 96.

McGovern M. and Tracy C. R. 1981. Phenotypic variation in electromorphs previously considered to be genetic markers in Microtus ochrogaster. Oecologia 51: 276 - 280.

Mezhzherin S. V. Allozyme variability and genetic divergence of long-tailed mice of subgenus Sylvaemus (Ognev et Vorobiev), Genetika 26: 1046 - 1054. [In Russian with English summary]

Mihok S. and Ewing D. 1983, Reliability of transferrin and leucine aminopeptidase phenotyping in wild meadow vole (Microtus pennsylvanicus). Biochem. Genet. 21: $969-983$.

Mihok S., Fuller W. A., Canham R. P. and McPhee E. C. 1983. Genetic changes at the transferrin locus in the red-backed vole (Clethrionomys gapperi). Evolution 37: $332-340$.

Moriwaki K., Sadaic T. and Hayato I. 1971. Genetic polymorphism of the serum transferrin in the field mouse, Apodemus giliam. Ann. Rep. Nat. Ins. Genet. 22; $21-22$.

Mueller J. O., Smithies O. and Irwin P. R. 1962. Transferrin variation in Columbidae. Genetics 43: $1385-1392$

Nascetti G. and Filippucci M. G. 1984. Variabilità e divergenza genetica in popolazioni italiane di Apodemus sylvaticus e Apodemus flavicollis (Rodentia, Muridae). Suppl. Ric. Biol. Selv. 9: 75 - 83 .

Nei M. 1977, $F$-statistics and analysis of gene diversity in subdivided populations. Ann. Hum. Genet. Lond. 41: $225-233$.

Nei M. 1978. Estimation of average heterozygosity and genetic distance from a small number of individuals. Genetics 89: 583 - 590 .

Nevo E. 1978. Genetic variation in natural populations: patterns and theory. Theor. Pop. Biol. 13: 831 -840 .

Nevo E. 1983. Population genetics and ecology: the interface. [In: Evolution from molecules to men. D. S. Bendall, ed]. Cambridge University Press, Cambridge: $287-321$.

Pavlenko M. V., Vorontsov N. N., Bekasova T. S. and Frisman L. 1984. [On species specificity of blood protein electrophoretic spectrum in Apodemus peninsulae and A. speciosus]. [In: Questions on the variability and zoogeography of mammals. K. V. Korobitsyna, T. S. Bekasova and L. V. Jakimenko, eds]. Akademia Nauk SSSR, Vladivostok: $30-42$. [In Russian]

Pemberton J. M., Albon S. D., Guinness F. E., Clutton-Brock T. H. and Berry R. J. 1988. Genetic variation and juvenile survival in red deer. Evolution 42: $921-934$.

Pucek Z., Jędrzejewski W., Jędrzejewska B. and Pucek M. 1993. Rodent population dynamics in a primeval deciduous forest (Białowieża National Park) in relation to weather, seed crop, and predation. Acta theriol. 38: $199-232$. 
Schade A. L. and Caroline L. 1944. Raw hen egg white and the role of iron in growth inhibition of Shigella dysenteriae, Staphylococcus aureus, Escherichia coli and Saccharomyces cerevisiae. Science 100: $14-15$.

Selander R. K., Smith M. H., Yang S. Y., Johnson W. E. and Gentry J. B. 1971. Biochemical polymorphism and systematics in the genus Peromyscus. I. Variation in the old-field mouse (Peromyscus polionotus). Studies in Genetics, Univ. Texas Publ. 7103: 49 - 90.

Semeonoff R. and Robertson F. W. 1968. A biochemical and ecological study of plasma esterase polymorphism in natural populations of the field vole, Microtus agrestis L. Biochem. Genet. 1: $205-227$.

Smith M. H., Garten C. T. and Ramsey P. R. 1975. Genic heterozygosity and population dynamics in small mammals. [In: Isozymes. IV. Genetic and evolution. C. L. Markert, ed]. Academic Press Inc., New York: $85-192$.

Smith M. H., Manlove M. N. and Joule J. 1978. Spatial and temporal dynamics of genetic organization of small mammal populations. [In: Populations of small mammals under natural conditions. D. P. Synder, ed]. Univ. Pittsburgh, Pittsburgh: 99 - 103.

Sokal R. R. and Rohlf F. J. 1981. Biometry. Second Edition. W. H. Freeman and Co., New York: $1-859$.

Southwood T. R. E. 1966. Ecological methods with particular reference to the study of insect populations. Methuen et Co. Ltd., London.

Taitt M. J. and Krebs C. J. 1985. Population dynamics and cycles. [In: Biology of New World Microtus. R. H. Tamarin, ed]. Special Publ. Amer. Soc. Mammal. 8: 567 - 620.

Tamarin R. H. and Krebs C. J. 1969. Microtus population biology II. Genetic changes at the transferrin locus in fluctuating populations of two vole species. Evolution 23: $183-211$.

Tomaszewska-Guszkiewicz K., Składanowska E. and Żurkowski M. 1971. Badania nad polimorfizmem amylazy surowicy krwi bydła nizinnego czarno-białego w Polsce. Biul. Inst. Genetyki i Hodowli Zwierząt PAN 24: 5 - 10. [In Polish]

Wołk E. and Kozłowski J. 1989. Changes of body weight and hematological parameters in the fluctuating population of yellow-necked mouse, Apodemus flavicollis. Acta theriol. 34: $439-464$.

Wójcik J. M. and Wołk K. 1985. The daily activity rhythm of two competitive rodents: Clethrionomys glareolus and Apodemus flavicollis. Acta theriol. 30: 241 - 258.

Workman P. L. and Niswander J. D. 1970. Population studies on southwestrn Indian tribes. II. Local genetic differentiation in the Papago. Amer. J. Hum. Genet. 22: $24-49$.

Wright S. 1965. The interpretation of population structure by $F$-statistics with special regard to systems of mating. Evolution 19: $395-420$.

Received 7 April 1993, accepted 10 October 1993. 